2. Trân Thị Anh Tú (2003), "Hình thái, cấu trúc tháp mũi người trưởng thành", Luận án tiến sĩ $Y$ hoc, Trường ĐHYD TP. Hồ Chí Minh.

3. Arima L. M. et al. (2011), "Crooked nose: outcome evaluations in rhinoplasty", Brazilian journal of otorhinolaryngology. 77 (4), pp. 510-515.

4. Foda H. M. (2005), "The role of septal surgery in management of the deviated nose", Plastic and Reconstructive Surgery. 115 (2), pp. 406-415.

5. Godley F. A. (1997), "Nasal septal anatomy and its importance in septal reconstruction", Ear, nose \& throat journal. 76 (8), pp. 498-506.

6. Mladina $\mathbf{R}$. et al. (2008), "Nasal septal deformities in ear, nose, and throat patients: an international study", American journal of otolaryngology. 29 (2), pp. 75-82.

7. Sam A. et al. (2012), "Nasal septal deviation and external nasal deformity: a correlative study of 100 cases", Indian Journal of Otolaryngology and Head \& Neck Surgery. 64 (4), pp. 312-318.

8. Stepnick D, Guyuron B (2010), "Surgical treatment of the crooked nose", Clinics in Plastic Surgery. 37 (2), pp. 313-325.

9. Yi J. S. et al. (2015), "Frequency and characteristics of facial asymmetry in patients with deviated noses", JAMA facial plastic surgery. 17 (4), pp. 265-269.

\title{
ĐĂC ĐIỂM LÂM SÀNG VÀ MộT SỐ YẾU Tố LIÊN QUAN CỦA BỆNH GIANG MAI TẠI BỆNH VIÊ̂N DA LIỄU TRUNG ƯO'NG
}

\author{
Trần Cẩm Vân*, Hoàng Thị Ái Liên*, Phạm Thị Minh Phương*
}

\section{TÓM TẮT}

Muc tiêu: Mô tả đặc điểm lâm sàng và một số yễu tổ liên quan của bệnh giang mai tại Bệnh viện $\mathrm{Da}$ liếu Trung ương từ tháng 4/2019 -6/2020. Đối tướng và phương pháp: Mô tả cắt ngang trên 339 bệnh nhân được chẩn đoán xác định bênh giang mai mới và chưa điều trị đến khám trong thời gian nghiên cứu. Kết quả: Tỉ lệ bệnh nhân giang mai trong các bệnh lây truyền qua đường tình dục là 9,33\%; trong đó $87 \%$ nhiếm giang mai đơn thuần, $5 \%$ có kết hợp với nhiễm HIV. Thể lâm sàng chủ yếu là giang mai kín muôn $44,8 \%$, tiếp theo giang mai 2 với $35,4 \%$, có $4,1 \%$ giang mai bẩm sinh. Chủ yếu nhóm tuổi 21-30 với $51,3 \%$, nam gặp nhiều hơn nữ $(79,7 \%$ so với $20,3 \%$ ), chưa có gia đình $66,1 \%$. Yếu tố nguy cơ quan hề tình dục không an toàn $75,5 \%$, quan hệ đồng giới $55,2 \%$. Đặc điểm lâm sàng chủ yếu của giang mai 1 là săng $(68,1 \%)$, giang mai 2 là sẩn $(74,6 \%)$. Kết luận: Bệnh giang mai là một vấn đề cần được xã hội quan tâm, đặc biệt với nhóm đối tượng nam giới trưởng thành, chưa có gia đình, có quan hệ đồng giới.

Từ khóa: Giang mai

\section{SUMMARY}

\section{CLINICAL CHARACTERISTICS OF PATIENT WITH SYPHILIS AND RELATED FACTORS} AT NATIONAL HOSPITAL OF

DERMATOLOGY AND VENEREOLOGY

Objectives: To investigate clinical characteristics and related factors of genital mycoplasma at National hospital of Dermatology and Venereology from 4/2019 to 6/2020. Population and methods: Crosssectional description of three hundred and thirdty-nine

*Bênh viên Da liễu Trung Ương.

Chịu trách nhiệm chính: Trân Cẩm Vân

Email: trancamvan.dl@gmail.com

Ngày nhận bài: 11.3.2021

Ngày phản biên khoa hoc: 13.5.2021

Ngày duyệt bài: 19.5.2021 patients with syphilis and no treatment before going to hospial. Results: The rate of patients with syphilis in sexually transmitted diseases was $9.33 \%$; of which $87 \%$ were syphilis alone, $5 \%$ co-infection with HIV. The main clinical stage was late syphilis $44.8 \%$, following syphilis stage of 2 with $35.4 \%$, congenital syphilis $4.1 \%$. Maily the age group $21-30$ with $51.3 \%$ men higher than women $(79.7 \%$ and $20.3 \%)$ unmarried $66.1 \%$. The risk factor for unprotected sex was $75.5 \%$, same-sex sexual activity $55.2 \%$. The main clinical feature of syphilis stage of 1 was chancres $68.1 \%$; stage of 2 was papuloma $74.6 \%$. Conclusion: Syphilis is an issue that needs to be of social concern, especially for group of men, unmarried and same-sex sexual activity.

Key words: syphilis

\section{I. Đă̆T VẤN ĐỀ}

Giang mai (Syphilis) là một bệnh nhiễm trùng kinh diễn do Treponema pallidum gây nên. Tứ thế kỷ XX, sau khi các nhà khoa học Đức mô tả xoắn khuẩn này, giang mai trở thành một bệnh dịch hiện đại, gây ảnh hưởng tới hàng triệu người trên thế giới [1]. Biểu hiện lâm sàng của bệnh đa dạng, dễ nhầm với các bệnh ngoài da khác, một số trường hợp sẩn giang mai phì đại ở hậu môn đã có chẩn đoán nhầm với sùi mào gà. Đặc biệt bệnh đã được chứng minh là góp phần làm tăng nguy cơ mắc và lây nhiễm HIV. Tổ chức $Y$ tế Thế giới (WHO) ước tính 17,7 triệu người trên toàn câuu từ 15-49 tuổi mắc bệnh, với khoảng 5,6 triệu người mắc mới mỗi năm [2]. Theo O’Byrne và cộng sự (2019), với khả năng lây nhiễm lên đến 10-30\% sau mỗi lần quan hệ tình dục, tỉ lệ bệnh đã tăng lên 300\% từ năm 2000 ở một số quốc gia Phương Tây [3]. Trong đó, bệnh có xu hướng gặp ở độ tuổi trẻ 25-34 tuổi, có nhiều bạn tình, $40 \%$ là đồng nhiễm với 
HIV. Tại Việt Nam, theo báo cáo của Bệnh viện Da liễu Trung Ương năm 2013, số ca mắc giang mai tăng từ 1394 bệnh nhân năm 2010 lên 2534 bệnh nhân năm 2011. Do đó, chúng tôi tiến hành nghiên cứu với mục tiêu mô tả đặc điểm lâm sàng và một số yếu tố liên quan của bệnh giang mai tại Bệnh viện Da liễu Trung ương từ tháng 4/2019-6/2020.

\section{II. ĐỐI TƯỢNG VÀ PHƯƠNG PHÁP NGHIÊN CỨU}

2.1. Đối tượng nghiên cứu. Tất cả bệnh nhân có chẩn đoán giang mai mới đến khám tại bệnh viện Da liễu Trung Ương từ tháng 4/2019 đến tháng 6/2020.

\subsubsection{Tiêu chuẩn lựa chọn}

+ Tất cả bệnh nhân có chẩn đoán xác đinh bệnh giang mai mới và chưa điêu trị dựa vào tiên sử quan hệ tình dục, lâm sàng và xét nghiệm.

+ Đồng ý tham gia nghiên cứu.

\subsubsection{Tiêu chuẩn loai trừ}

+ Bệnh nhân mắc bệnh giang mai đang và đã điêu trị.

+ Bệnh nhi, phụ nữ có thai và cho con bú.

+ Bệnh nhân không hợp tác hoặc mắc bệnh tâm thần, nghiện rượu, ma túy.

\subsection{Phương pháp nghiên cứu}

2.2.1. Thiết kế nghiên cứu: Mô tả cắt ngang

2.2.2. Cõ mẫu: Cõ mẫu thuận tiện

2.2.3. Các bước tiến hành nghiên cứu

- Phỏng vấn để thu thập thông tin cá nhân, tiền sử, bệnh sử

- Khám lâm sàng, xét nghiệm, lựa chọn bệnh nhân và phỏng vấn để thu thập các thông tin cân thiết (theo phụ lục).

- Làm đồng bộ các xét nghiệm sau:

+ Nễu bệnh nhân có biểu hiện lâm sàng của giang mai 1 và giang mai 2 thì lấy bệnh phẩm tại tổn thương để soi tươi và nhuộm soi tìm xoắn khuẩn giang mai.

+ Sàng loc giang mai bằng test nhanh, nếu dương tính làm tiếp các xét nghiệm RPR, TPHA.

2.3. Phương pháp xử lý số liệu. Xử lý số liệu theo phương pháp thống kê y học, sử dụng phân mềm SPSS 16.0. Sự khác biệt giữa 2 nhóm nghiên cứu có ý nghĩa thống kê nếu $p<0,05$.

\section{KẾT QUẢ NGHIÊN CỨU}

Từ tháng 4/2019 đến tháng 6/2020, có 3631 bệnh nhân mắc bệnh lây truyền qua đường tình dục, trong đó 339 bệnh nhân giang mai mới, chiếm tỉ lệ 9,33\%. Kết quả như sau:

$$
\begin{array}{r|c}
\text { HIV + Sùi mào gà + Giang mai } & 0.9 \\
\text { Sùi mào gà + Giang mai } & 3.2 \\
\text { C. trachomatis + Giang mai } & 2.7 \\
\text { Lậu cầu + Giang mai } & 1.2 \\
\text { HIV + Giang mai } & 5
\end{array}
$$

Giang mai đơn thuần

$$
\begin{array}{llllll}
0 & 20 & 40 & 60 & 80 & 100
\end{array}
$$

Biểu đồ 3.7. Tỉ lệ nhiễm phôi hợp của các tác nhân với Giang mai (n=339)

\begin{tabular}{|c|c|c|c|}
\hline \multicolumn{2}{|c|}{ Đăc điếm } & $\mathbf{n}$ & $\%$ \\
\hline \multirow{5}{*}{ Tuổi } & Bấm sinh & 14 & 4,1 \\
\hline & $18-20$ & 87 & 25,7 \\
\hline & $21-30$ & 174 & 51,3 \\
\hline & $31-40$ & 53 & 15,6 \\
\hline & $41-49$ & 11 & 3,3 \\
\hline \multirow{2}{*}{ Giới } & Nam & 270 & 79,7 \\
\hline & Nữ & 69 & 20,3 \\
\hline \multirow{3}{*}{$\begin{array}{l}\text { Tình trang } \\
\text { hôn nhân }\end{array}$} & Có gia đình & 115 & 33,9 \\
\hline & Chưa có gia đình & 224 & 66,1 \\
\hline & ống số & 339 & 100 \\
\hline
\end{tabular}

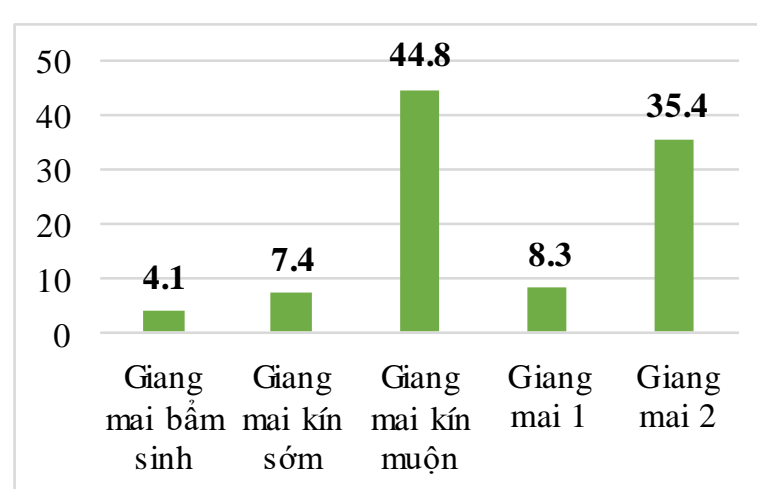

Biểu đồ 3.8. Phân loại thể lâm sàng của bệnh nhân giang mai $(n=339)$
Bảng 3.6. Một số đặc điểm chung của bệnh nhân giang mai $(n=339)$

Bảng 3.7. Một số yếu tố nguy cơ của bệnh nhân giang mai $(n=339)$ 


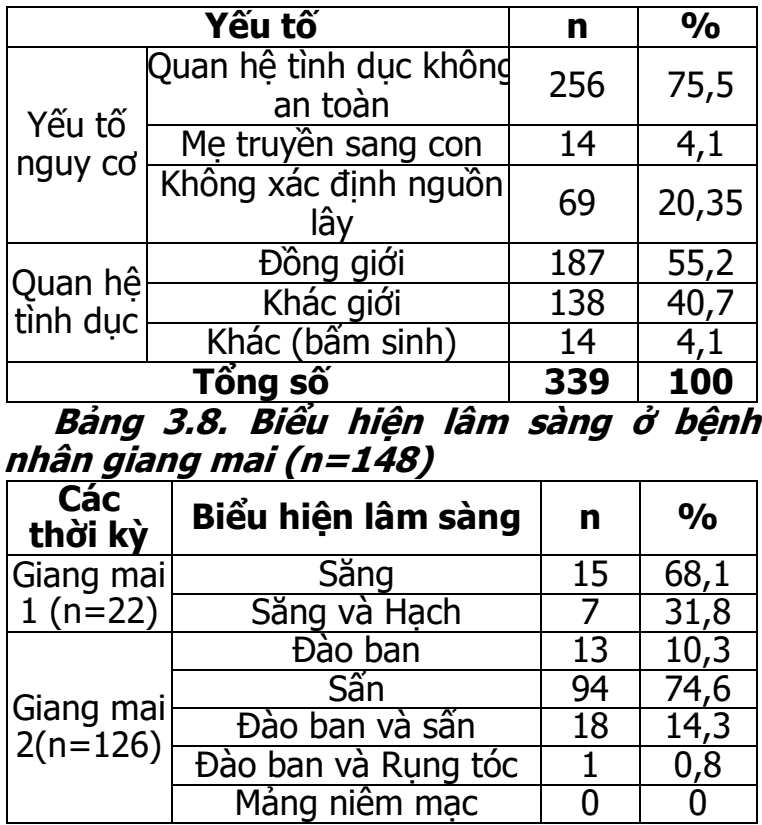

\section{BÀN LUÂN}

Trong những năm gần đây, tỉ lệ mắc giang mai ngày càng gia tăng trong cộng đồng. Kết quả của chúng tôi cho thây tỉ lệ mắc giang mai trong số các bệnh lây truyền qua đường tình dục là 9,33\%, trong đó, hầu hết là bệnh nhân mắc giang mai đơn thuân. Trong số những trường hợp đồng nhiễm, thường gặp nhất là đồng nhiễm HIV với tỉ lệ $5 \%$; chỉ có $0,9 \%$ đồng nhiễm ba bệnh giang mai, HIV và sùi mào gà. Theo Mao và cộng sự (2014), tỉ lệ đồng nhiễm giữa HIV và giang mai là $11,52 \%$ [4]. Một báo cáo khác của Callegari và cộng sự (2014) cho thấy, tỉ lệ mắc giang mai trên những bệnh nhân HIV/AIDS là 5,3\%. Theo nhóm nghiên cứu, có thể do triệu chứng lâm sàng đa dạng với nhiều hình thái khác nhau; đồng thời, diễn tiến âm thầm, không gây cho khó chịu cho bệnh nhân như các bệnh lây truyền qua đường tình dục khác. Vì vậy, bệnh nhân dễ dàng bỏ qua, bệnh có cơ hội lây lan ra cộng đồng nhiều hơn. Các tổn thưởng giang mai thời kỳ 1 và 2 rất dễ lây nhiễm thêm các bệnh nhiễm trùng đường tình dục khác và càng làm tăng lây nhiễm HIV.

- Về các giai đoạn bệnh: Báo cáo của Baigalmaa và cộng sự (2012) về tình hình bệnh giang mai tại Mống cổ trong giai đoạn 10 năm từ 2001-2011 cho thấy, tỉ lệ trên 100.000 dân của giang mai kín là 134 , cao hơn so với giang mai 1 là 27 và giang mai 2 là 49 trường hợp [5]. Kết quả của chúng tôi tương đồng với tác giả, tỉ lệ mắc giang mai kín muộn là $44,8 \%$, cao hơn giang mai 1 là $8,3 \%$ và giang mai 2 là $35,4 \%$.
Các triệu chứng của giang mai kín thường không gây đau đớn, khó chịu và tự mất đi dù không điều trị làm cho bệnh nhân lầm tưởng bệnh đã khỏi. Tuy nhiên, bệnh giang mai vẫn tiềm tàng và lây nhiễm mạnh trong cộng đồng. Bệnh chì được phát hiện khi bệnh nhân đi kiểm tra sức khỏe, được làm các phản ứng huyêt thanh chẩn đoán giang mai.

- Vê tuổi và giới: bảng 3.1 chỉ ra rằng, nhóm từ 21-30 chiếm tỉ lệ cao nhất với $51,3 \%$, tiếp đó là nhóm $18-20$ với $25,7 \%$. Kết quả này tương tự như báo cáo của các tác giả khác trên thế giới như O’Byrne và cộng sự (2019) nhóm 25-34 tuổi chiếm chủ yếu [3], hay Baigalmaa và cộng sự (2012) là nhóm 20-29 tuổi. Đây là nhóm tuổi sinh sản và hoạt động tình dục nhiều nhất. Peeling và cộng sự (2017) cho rằng, ở các nước có thu nhập trung bình và thấp, giang mai là vấn đề thường gặp ở nhóm phụ nữ mại dâm và khách hàng nam của họ. Theo thống kê của tác giả, tại Trung Quốc, tỉ lệ mắc giang mai xấp xỉ $5 \%$ ở nhóm phụ nữ mại dâm và $3 \%$ trong số khác hàng nam của họ [2]. Nghiên cứu của chúng tôi có $79,7 \%$ nam giới mắc bệnh, chỉ $20,3 \%$ là nữ giới. Nhóm nghiên cứu cho rằng có thể do nam giới là người chủ động trong quan hệ tình dục nhiều hơn nữ giới và nhóm nam quan hệ đồng giới ngày càng cao nên tỷ lệ nhiễm giang mai cao hơn.

- Về nhóm quan hệ tình dục: Bảng 3.2 cho thấy tỷ lệ bệnh giang mai ở đối tượng có quan hệ tình dục đồng giới nam cao chiếm tới 57,4\%, còn quan hệ khác giới chiếm 42,6\%. Nghiên cứu của chúng tôi tương tự như O'Byrne và cộng sự (2019), giang mai có xu hướng gặp nhiêu hơn ở đối tượng quan hệ tình dục đồng giới[3]. Nghiên cứu của Viện Vệ sinh dịch tễ Trung ương ở 6 tỉnh thành trên 3 nhóm đối tượng: nhóm tiêm chích ma túy, phụ nữ mại dâm và nam quan hệ tình dục đồng giới, kết quả cho thấy tỷ lệ nhiễm HIV và STD cao nhất ở nhóm MSM, cụ thể tỷ lê nhiễm HIV là trên $10 \%$ trong đó ở Hà Nội là $20 \%$, còn ở TP Hồ Chí Minh thì cứ năm người MSM có một người nhiễm một trong các bệnh STD sau: giang mai, lậu sinh dục, lậu trực tràng, Chlamydia sinh dục hoặc trực tràng [6]. Trong quan hệ tình dục nam-nam, hành vi quan hệ tình dục qua đường hậu môn đem lại nguy cơ lây nhiễm HIV và STIs cao nhất trong tất cả các loại hình thức nếu không áp dụng biện pháp bảo vệ. Hành vi này thực sự rất nguy hiểm cho những người thực hành chúng bởi hậu môn không có cơ chế tiết dịch bôi trớn và giảm đau như khi có quan hệ tình dục qua đường âm đạo đối với nữ. 
Hơn nữa, niêm mạc trực tràng có nhiêu mao mạch dễ bị tổn thương xây xước khi có quan hệ qua đường này. Có thể tính miễn dịch tế bào tại đường vòng hậu môn thấp hơn so với tính miễn dịch tế bào tại âm đạo, khả năng tự bảo vệ khi có quan hệ tình dục không an toàn thấp.

- Về đặc điểm lâm sàng: Trong 22 bệnh nhân, giang mai 1 có $68,1 \%$ bệnh nhân có săng và $31,8 \%$ bệnh nhân có cả săng và hạch. Trong 126 bệnh nhân giang mai 2 có 74,6\% bệnh nhân chỉ có sẩn, $10,3 \%$ chỉ có đào ban, $14,3 \%$ có cả sẩn và đào ban và có 1 bệnh nhân có đào ban và rụng tóc và không gặp mảng niêm mạc trong giang mai 2.

Săng giang mai thời kỳ 1 vẫn điển hình là vết trợt nông, không đau chiếm tỷ lệ $86,36 \%$ và đáy thương tổn rắn $(95,45 \%)$. Như vậy, các đặc điểm lâm sàng của giang mai thời kỳ 1 và thời kỳ 2 dường như không thay đổi trong những năm gần đây. Chỉ thấy rõ rằng trên những bệnh nhân nhiễm HIV, các tổn thương lâm sàng có sự biến đổi, do đó dễ chẩn đoán nhầm và làm chậm trễ quá trình điều trị, sẽ càng làm phát tán bệnh giang mai ra công đồng và cũng là nguyên nhân gây lây nhiễm HIV. Do đó việc nhận biết các tổn thướng giang mai không điển hình trên người nhiễm HIV là rất quan trọng để phát hiện sớm và có phương pháp điêu trị kịp thời

\section{KẾT LUÂN}

Cho đến nay, bệnh giang mai là một bệnh có tính chất "xã hội" cần được quan tâm. Bệnh có xu hướng gặp nhiều hơn ở đối tượng nguy cơ cao bao gồm nam giới, chưa có gia đình, có quan hêe tình dục không an toàn và quan hệ đồng giới. Đặc biệt, có một tỉ lệ bệnh nhân đồng nhiếm với các bệnh lây truyền qua đường tình dục khác, trong đó có HIV. Do đó, cần tuyên truyền, giáo dục hành vi, nâng cao nhận thức cho các nhóm đối tượng nguy cơ cao.

\section{TÀI LIẸU THAM KHẢO}

1. Nyatsanza F., Tipple C. (2016). Syphilis: presentations in general medicine. Clin Med (Lond), 16(2), 184-188.

2. Peeling R.W., Mabey D., Kamb M.L. et al (2017). Syphilis. Nature Reviews Disease Primers, 3(1), 17073.

3. O'Byrne P., MacPherson P. (2019). Syphilis. Bmj, 365, 1-7.

4. Mao H., Ma W., Lu H. et al (2014). High incidence of HIV and syphilis among migrant men who have sex with men in Beijing, China: a prospective cohort study. BMJ Open, 4(9), 1-10.

5. Baigalmaa J., Erdenechimeg C., Narantuya J. et al (2012). Increasing syphilis notifications in Mongolia: results from national surveillance for 20012011. Western Pac Surveill Response J, 3(4), 86-93.

6. Viện vệ sinh dịch tế Trung Ương (2011), Kết quả giám sát kết hợp hành vi và các chỉ số sinh học HIV/STI (IBBS) vòng II-2009.

\section{NGHIÊN CỨU ĐĂC ĐIỂM TUỔI, GIỚI VÀ MỐI LIÊN QUAN ĐẾN TỈ LỆ NHIỄM VIRUS DENGUE Ở BỆNH NHÂN NHI}

\section{TÓM TẮT}

Muc tiêu: Phân tích làm rõ đặc điểm tuổi, giới và mối liển quan đến đến tỉ lệ nhiễm virus dengue ở bệnh nhân nhi. Đối tượng và phương pháp nghiên cứu: 344 bệnh nhân nhi được chẩn đoán sốt xuất huyết Dengue giai đoạn cấp tính trong vòng 3 ngày của sốt, được nhập viện điêu trị tại khoa nhi bệnh viện Nhi Đồng 1 , bệnh viện Tiền Giang và bệnh viện Nhi Đồng Đồng Nai từ tháng 1-2011 đến tháng 122015.Tất cả các bênh nhân đều được thân nhân và người nhà đồng ýy tham gia nghiên cứu. Tiến hành thu thập thônng tin tuổi giới, huyết thanh của bệnh nhân, tách RNA. Sử dụng phản ứng Multiplex RT-PCR xác

${ }^{1}$ Bệnh viện Quân y 103

${ }^{2}$ Hoc viên Quân y

Chịu trách nhiệm chính: Đặng Thành Chung

Email: dangthanhchung@vmmu.edu.vn

Ngày nhận bài: 10.3.2021

Ngày phản biên khoa học: 10.5.2021

Ngày duyệt băi: 17.5.2021

\section{Nguyễn Đức Thuận ${ }^{1}$, Đặng Thành Chung ${ }^{2}$}

định các type huyết thanh của virữ DENV. Kết quả: Bệnh nhân ở các khoảng tuổi nhiếm cả 4 type virus: type 1 (DENV-1), type 2 (DENV-2), type 3 (DENV-3) và type 4 (DENV-4). Trong đó khoảng khoảng tuổi 6 10 chiếm tỉ lệ cao nhất $(50,43 \%-63,24 \%)$, sau đó là khoảng tuổi $11-15(23,53 \%$ - 38,46\%), và thấp nhất là khoảng tuổi $\leq 5(11,11 \%-15,79 \%)$ ở cả 4 type virus, tuy nhiên không có sự khác biệt về tuổi giữa các type virus, với $p=0,1338$. Tỉ lệ nhiễm virus của hại giới là tương đương nhau ở các type virus 1,2 và 4 . Ơ type 3 tỉ lệ ở nữ $(63,16 \%)$ cao hơn ở nam $(36,84 \%)$, tuy nhiên sự khác biệt giữa hai giới không có ý nghĩa thống kê với $p=0,2513$. Kết luận: Không có sự khác biệt về tuổi và giới giữa các trường hợp nhiếm các type virus khác nhau, tuy nhiên ở độ tuổi 6-10 nhiễm virus chiếm tỉ lệ cao nhất ở cả 4 type, tỉ lệ nhiễm type 3 ở nữ cao hơn ở nam.

Tư khóa: tuổi, giới, virus denge, type huyết thanh, nhi.

\section{SUMMARY}

STUDY ON AGE, GENDER 